\title{
Model Manajemen Bisnis dan Komunikasi Pemasaran Stasiun Radio di Era Digital dan Revolusi Industri 4.0
}

\author{
Sadeli $^{1}$, Edwi Arief Sosiawan ${ }^{2}$ \\ ${ }^{1}$ Progam Studi Ilmu Administrasi Bisnis, ${ }^{2}$ Program Studi Ilmu Komunikasi, \\ ${ }^{1,2}$ Fakultas Ilmu sosial dan Ilmu Politik, Universitas Pembangunan Nasional "Veteran" Yogyakarta \\ Jl Babarsari 2 Sleman Yogyakarta, 55281, Indonesia \\ Email: sadelisahadati@gmail.com ${ }^{1 *}$; edwias@upnyk.ac.id ${ }^{2}$ \\ *Corresponding author
}

\begin{abstract}
The competition in the radio broadcast business is increasingly booming because of the tight competition conditions for channels in Yogyakarta accompanied by conditions of social change due to the 4.0 revolution. The digitalization of the 4.0 industrial revolution has also decreased the number of radio listeners because it is easier to get information and music that has been obtained only from the radio. I-Radio Jogja as a networked radio certainly has challenges in competing with old radio business players in Yogyakarta apart from other new radios. This study aims to find a business management model and marketing communication for radio stations in the era of digitalization of revolution 4.0. The method used is a descriptive qualitative method. The results showed that the radio business management model should prioritize local content by combining music and information shows. Primetime for young people as listeners is in the morning and evening. From the client-side, the ideal management model is to use discount offers and consider the balance of both parties' benefits with offers integration with other radio networks. Keywords: Business Management; Marketing Communication; Radio
\end{abstract}

\begin{abstract}
Abstrak
Persaingan bisnis siaran radio semakin membuncah karena kondisi persaingan kanal yang rapat di Yogyakarta disertai dengan kondisi perubahan sosial akibat adanya revolusi 4.0. Digitalisasi dari revolusi industri 4.0 turut menurunkan jumlah pendengar radio karena lebih mudah mendapatkan informasi dan musik yang selama ini diperoleh hanya dari radio. I-Radio Jogja sebagai radio berjaringan tentunya memiliki tantangan dalam bersaing dengan pemain lama bisnis radio di Yogyakarta selain radio baru lainnya. Penelitian ini bertujuan menemukan model manajemen bisnis dan komunikasi poemasaran stasiun radio di era disgitgalisasi revolusi 4.0. Metode yang digunakan adalah metode kualitatif deskriptif. Hasil penelitian menunjukkan model manajemen bisnis radio harus mengedepankan konten lokal dengan menggabungkan antara acara musik dan informasi. Waktu prime time untuk kalangan muda sebagai pendengar adalah saat pagi dan sore hari. Dari sisi klien model manajemen yang ideal adalah menggunakan penawaran diskon dan mempertimbangkan keseimbangan keuntungan kedua belah pihak dengan penawaran terintegrasi dengan jaringan radio lainnya. Kata kunci: Manajemen Bisnis; Komunikasi Pemasaran; Radio
\end{abstract}

\section{Pendahuluan}

Revolusi industri 4.0 merupakan revolusi industri yang dapat dibedakan dengan revolusi industri sebelumnya. Revolusi industri generasi ke-4 ini memiliki skala, ruang lingkup dan perbincangan yang lebih luas. Kemajuan teknologi baru mengintegrasikan dunia fisik, digital dan biologis telah mempengaruhi semua disiplin ilmu, ekonomi, industri dan pemerintahan. Kondisi ini menjadikan banyak terjadi perubahan dalam diri masyarakat yang mulai beralih menkonsumsi media bukan lagi pada media massa arus utama namun beralih kepada media digital yang salah satunya didominasi oleh media internet serta media sosial seperti Instagram, Facebook dan Youtube. Fakta-fakta tersebut dapat dilihat dari fenomena Penurunan tingkat kepembacaan selama beberapa tahun terakhir, memberikan dampak yang cukup signifikan terhadap keberlangsungan berbagai media. CNBC Indonesia menyebutkan sejak tahun 2017 beberapa media konvensional di Indonesia memutuskan untuk menghentikan bisnis cetak dan beralih ke media online. data ini selanjutnya didukung oleh PricewaterhouseCoopers (PwC), lembaga audit 
dan konsultan global yang berbasis di London, memprediksi bahwa tahun 2021 industri E\&M Indonesia hanya mampu meraup pendapatan US\$23-US\$25 miliar, di bawah rata-rata pendapatan negara yang disurvei US\$41 miliar.

Kondisi ini juga terjadi dengan bisnis industri penyiaran radio, beberapa stasiun radio swasta juga mulai tumbang satu persatu, karena semakin lama semakin sedikit sekali masyarakat yang mendengarkan siaran radio. Penyebab utamanya adalah akibat bertumbuh pesatnya penetrasi dunia internet. Akses informasi dan konten sesuai kebutuhan sudah sangat cepat dan dimudahkan, dalam hitungan detik informasi sudah didapatkan yang bersifat interaktif. Kondisi ini menjadi salah satu penyebab masyarakat mulai beranjak meninggalkan radio (Lestari, 2018, 10^0. Berdasarkan survey Nielsen 2018, tiap tahun, pendengar radio mengalami penurunan hingga $3 \%$. Sedangkan sebagai media promosi, radio hanya memiliki porsi penetrasi $30 \%$ penggunaan di tengah masyarakat, dibanding televisi, majalah dan media lainnya. Penurunan jumlah pendengar radio juga disebabkan karena kemudahan mendapatkan lagu lewat internet, mengakses informasi lewat android dan tidak adanya lagi rasa bangga dan spesial ketika lagu yang diminta masyarakat diputar di radio kesayangan mereka.

Persoalan lain adalah pembagian kue iklan yang sejak era tahun 1990-an yang sudah termakan media televisi memperarah kondisi bisnis stasiun radio. Kondisi saat ini radio semakin sulit mendapat iklan, semakin tergerus dengan media daring dan media sosial, Meskipun beberapa stasiun radio sudah berusaha keras untuk mengimbanginya dengan terobosan teknologi, namun hal ini belum mampu meraih kembali jumlah pendengar yang ideal, sehingga biaya operasionalpun tak tertutupi yang berujung pada tumbangnya stasiun radio tersebut.

Komisi Penyiaran Indonesia Daerah (KPID) Yogyakarta sendiri sudah menerangai bahwa kondisi industri bisnis siaran radio di Yogyakarta kian kritis. Penetrasi iklan yang bisa diraih hanya
$0.9 \%$, sementara stasiun radio di Yogyakarta melampaui jumlah ideal radio yang berbanding denga luas wilayah dan jumlah penduduk. Kondisi di Yogyakarta sendiri terdapat 40 Stasiun radio beberapa diantaranya sudah tidak bertahan bahkan kemudian terjadi praktek jual beli radio atau frekuensi. Efek lain adalah beberapa stasiun radio saling menyerang satu sama lain dengan memperbesar power transmitter sehingga menutupi frekeunsi stasiun radio lain.

Selain efek saling menutupi frekuensi, kondisi bisnis radio di Yogyakarta juga terjadi spasialisasi yaitu proses integrasi antar media dan perpindahtanganan kapital maupun otoritas di antara pihak-pihak yang terlibat di dalamnya termasuk perluasan jangkauan siaran (Maulana, 2019, 62). Keseragaman program di antara radio-radio yang masuk dalam ranah spasialisasi adalah salah satu dampak yang muncul dari integrasi yang dilakukannya. Pola kepemilikan media yang terkonsentrasi seperti ini memengaruhi keberagaman konten siaran radio sehingga masyarakat tidak lagi dapat menikmati keberagaman informasi dan hiburan yang menyudutkan radio menjadi media yang membosankan.

Dengan demikian dapat dilihat bahwa terdapat beberapa identifikasi masalah dari paparan di atas bahwa ancaman terhadap bisnis siaran radio di Yogyakarta dalam kondisi kritis akibat persaingan dan kondisi penurunan jumlah pendengar radio akibat beralih ke media daring dan digital. Oleh karena itu rumusan masalah yang diambil dalam penelitian ini adalah "Bagaiamana model manajemen bisnis dan komunikasi pemasaran radio yang ideal dalam era digitalisasi media dan revolusi industri 4.0 di Yogyakarta?"

Subjek yang dipilih dalam penelitian ini adalah I-Radio jogja dengan beberapa pertimbangan yaitu (a). I-Radio Jogja merupakan radio yang mengedepankan musik Indonesia terbaik dan berkualitas dalam program siaran musik yang seratus prosen musik Indonesia, (b). I-Radio Jogja merupakan radio jaringan 
yang mampu mematahkan dominasi radio lokal di Yogyakarta dan bersaing dalam kualitas siaran dan meraih penggemar serta kue iklan, (c) I-Radio Jogja telah menjadi barometer perjalanan dan perkembangan musik Indonesia bagi para insan musik dan musisi Indonesia, dan menjadi referensi musik Indonesia yang terlengkap bagi masyarakat.

Penelitian ini melihat dari dua prespektif yaitu manajemen bisnis dan komunikasi pemasaran sebagai tulang punggung bisnis siaran radio yang belum banyak diungkapan dalam penelitian ilmiah sejak bergemanya revolusi industri 4.0. Umumnya penelitian melihat strategi komunikasi pemasaran radio lakal semata seperti tesis Kastaya (2014) yang meneliti tentang strategi komunikasi pemasaran radio lokal di Surabaya kurun waktu 2010-2014, sedangkan penelitian yang menyoal manajeman bisnis siaran radio belum banyak ditemukan dan umumnya lebih mengarah pada manajemen siaran radio seperti penelitian Rihartono (2015) yang mengulik strategi pengelolaan radio siaran di tengah-tengah perkembangan teknologi internet. Sementara mengangkat tema manajemen bisnis radio lokal belum banyak diteliti namung lebih menbgarah pada konten siaran yang dilaksanakn seperi penelitian Anindhita (2013).

\section{Manajemen Bisnis Siaran}

Manajemen bisnis media dipandang sebagai disiplin administrasi bisnis yang mengidentifikasi dan menggambarkan fenomena dan masalah strategis dan operasional dalam kepemimpinan perusahaan media. Manajemen media berisi fungsi manajemen strategis, manajemen pengadaan, manajemen produksi, manajemen organisasi dan pemasaran perusahaan media. Manajemen Media terdiri dari; kemampuan untuk mengawasi dan memotivasi karyawan dan kemampuan untuk mengoperasikan fasilitas dan sumber daya dengan cara yang hemat biaya agar menguntungkan (Sherman, 1995, 17). Sementara pendapat lain mengatakan bahwa tugas inti manajemen media adalah membangun jembatan antara disiplin teori manajemen umum dan kekhasan industri media (Küng, 2008).

Wahyudi (2016:39) menyatakan manajemen penyiaran adalah merupakan proses perencanaan, pengorganisasian, kepemimpinan dan pengendalian suatu kegiatan penyiaran yang dilakukan secara proporsional dan professional untuk mencapai target atau sasaran yang telah ditentukan, terdiri atas: (a) Perencanaan (planning): menyiapkan rencana dan strategi yang akan dikerahkan guna mencapai tujuan perusahaan penyiaran. Dalam tahapan ini harus sudah tahu tentang apa yang harus dilakukan, kapan, bagaimana, dan siapa yang akan menjalankan rencana tersebut. Radio harus memiliki Visi dan Misi perusahaan yang menjadi acuan pembuatan sebuah rencana perusahaan. (b) Pengorganisasian (Organizing); Tanggung jawab dalam menjalankan sebuah radio terbagi menjadi dua kategori, yaitu manajemen penyiaran dan pelaksanaan operasional penyiaran. (c) Pengaruh mengarahkan dan memberikan pengaruh memiliki tujuan agar merangsang antusiasme karyawan dalam menjalankan tanggung jawab kerja secara efektif. Fungsi memengaruhi atau mengarahkan fokus pada stimulasi karyawan dalam melaksanakan tanggung jawab yang dimiliki secara antusias dan efektif(Peter Pringle, 1991),(d)Pengawasan(Controlling), pengawasan dilakukan berdasarkan kinerja karyawan yang bisa diukur agar penilaian berjalan secara efektif.

Menurut Undang-undang penyiaran No. 32 Tahun 2002 yang disebut lembaga penyiaran adalah lembaga yang menyelenggarakan jasa penyiaran yang terdiri dari lembaga penyiaran publik, swasta, komunitas dan berlangganan. Dalam UU tersebut lembaga penyiaran adalah organisasi yang memproduksi siaran yang berbentuk stasiun baik radio maupun televisi. Secara operasional salah satu jenis stasiun yang harus melaksankan kegiatan manajemen dan mencari keuntungan finasial adalah stasiun penyiaran swasta. Ada hal yang harus dilakukan 
dalam manjemen bisnis siaran swasta yaitu manajemen pengeloaan siaran dan manajemen pemasaran siaran. Menurut Mogel (2014) dalam melaksanakan manajemen bisnis siaran maka yang perlu dipertimbangkan adalah: (a) Investasi atau Modal dalam bisnis media merupakan faktor penting karena menjadi kekuatan agar media dapat menjalankan fungsinya sebagai pembuat konten siaran serta memberikan fasilitasi pada pelaku atau pekerja siaran dalam lembaga penyiaran. (b) Sumber Daya Manusia (SDM) atau pekerja media merupakan kekuatan utama lainnya dalam sebuah bisnis media massa. Modal yang kuat belum tentu mampu menyelenggarakan kegiatan siaran dengan baik bila tidak didukung oleh kompetensi SDM pekerja media. (c) Teknologi: peralatan yang sesuai dengan perkembangan teknologi menjadi poin ketiga dalam memberikan kontribusi dalam bisnis media. Teknologi menjadi bagian dalam strategi penyebarluasan siaran dan menjaga kualitas siaran harus mutlak dipenuhi dalam manajemen bisnis siaran terkait pemberian kepuasan audiens. (d) Media sebagai entitas ekonomi dalam ranah bisnis, media sama halnya dengan perusahaan lainnya yang juga harus berorientasi pada profit. Namun, perbedaan institusi media massa dengan media lainnya adalah, produk yang dihasilkan bisnis media massa adalah produk yang mempengaruhi pemikiran, cara pandang, sikap dan perilaku khalayak terhadap lingkungan. Pada produk tersebut, harus ada kompromi antara idealism, komersialisme dalam balutan profesionalisme. (e) Regulasi Media Regulasi media dalam skala kebijakan, juga sangat menentukan iklim pertumbuhan media massa.

\section{Komunikasi Pemasaran}

Menurut Kotler (2012, 563) "Suatu cara memandang keseluruhan proses pemasaran dari sudut pandang pelanggan" Pada dasarnya, komunikasi pemasaran adalah proses penting untuk menyampaikan pesan antara perusahaan dan konsumen yang membuat khalayak sasaran percaya. merek dan pemasar Burnett (1993).
Ini memiliki metode yang berbeda untuk menjangkau khalayak tetapi tujuan utamanya adalah untuk membangun media yang dapat menginformasikan dan membujuk konsumen. Juga, komunikasi pemasaran adalah metode untuk membangun hubungan yang tidak terlihat antara perusahaan dan pelanggan. Untuk memastikan audiens menerima pesan dengan benar adalah langkah utama. Dengan menggunakan komunikasi pemasaran, konsumen dapat memahami tentang perusahaan, produk dan merek (Kotler dan Keller, 2012).

Secara tradisional, ada beberapa elemen dalam komunikasi pemasaran yang meliputi periklanan, promosi penjualan, sponsor, hubungan masyarakat, pemasaran langsung, dan penjualan pribadi (Pickton dan Broderick, 2005). Padahal sudah ada beberapa elemen yang dibedakan untuk membedakannya. Masih ada beberapa ruangan yang tumpang tindih. Oleh karena itu, ini menunjukkan pentingnya komunikasi pemasaran terintegrasi. Selain itu, telah diklaim bahwa ada beberapa alat yang juga dapat dalam bauran komunikasi pemasaran seperti kemasan, dari mulut ke mulut, titik penjualan,

Alasan utama untuk memilih bauran pemasaran yang terintegrasi adalah bahwa pesan dan informasi dapat secara luas menjangkau audiens target dengan semua saluran serta metode yang lebih cocok dan efektif untuk mencapai tujuan komunikasi pemasaran (Ivanova \& Dennis, 2018:9). Dengan promosi multi-saluran, ini meningkatkan kesadaran merek dan memahami pesan. Oleh karena itu, setiap elemen bauran komunikasi pemasaran memiliki fungsi khusus untuk mempromosikan merek dalam kampanye pemasaran. Saat ini, iklan TV, sponsor, promosi penjualan adalah alat komunikasi pemasaran yang populer dan penting untuk digunakan dalam kampanye promosi bir. Juga, telah ditemukan bahwa katakata dari mulut ke mulut memainkan peran utama untuk mempengaruhi beberapa pelanggan bir. Elemen-elemen bauran komunikasi pemasaran ini dibahas seperti di bawah ini. 
Periklanan adalah elemen utama dalam bauran komunikasi pemasaran. Adalah umum untuk menemukan bahwa mayoritas audiens menganggap iklan sama dengan promosi. Menurut Kotler dan Keller (2012) "Segala bentuk presentasi dan promosi ide, barang, atau jasa non-pribadi yang dibayar oleh sponsor yang teridentifikasi." Ini adalah definisi umum dari iklan tetapi menunjukkan titik karakteristik kunci yang merupakan promosi untuk produk atau layanan oleh sponsor. Sedangkan Sponsorship berada dalam sub-kategori hubungan masyarakat yaitu membangun hubungan dan citra perusahaan (Kotler dan Armstrong, 2012). Definisi sponsorship adalah bahwa perusahaan menginvestasikan uang atau sejenisnya untuk mengharapkan pendapatan potensial untuk mencapai tujuan pemasaran (Meenaghan, 1991).

Promosi penjualan adalah promosi jangka pendek untuk merangsang perilaku pembelian konsumen (Kotler dan Armstrong, 2012). Fungsi promosi penjualan tidak sama dengan elemen lain yang meningkatkan hubungan jangka panjang dengan konsumen. Ini berfokus untuk meningkatkan penjualan segera. Ada dua cara untuk mencapai penjualan. Salah satunya adalah untuk mendorong pelanggan saat ini membeli lebih banyak produk atau yang lain adalah untuk menarik perhatian pelanggan baru untuk membeli. Berbeda dengan word of mouth adalah media yang kuat untuk komunikasi pemasaran. Sulit untuk bersaing dengan rekomendasi teman dengan iklan atau elemen campuran komunikasi lainnya. Juga, telah diklaim bahwa konsumen lebih mungkin untuk mengubah preferensi merek mereka dengan saran daripada bauran promosi. Words of mouth dapat menjadi alat untuk menembus penghalang. Dengan perkembangan internet, saluran komunikasi nyaman dan informasinya terlalu banyak. Pengalaman dan perasaan dapat menyebar sangat cepat yang tidak seperti elemen campuran komunikasi lainnya yang tidak dapat diukur dan dikendalikan hanya oleh promotor.

Salah satu teori utama dalam kerangka komunikasi pemasaran adalah hierarki efek model yang secara logis menjelaskan tugas sekuensial pengaruh pesan pemasaran. Dengan kata lain, itu mempengaruhi kesadaran konsumen untuk membeli tindakan yang diasumsikan bahwa langkah relatif idealnya akan mendorong proses selanjutnya. Proses pertama adalah bagian kognitif yang berarti konsumen telah menerima pesan dan suka kesadaran. Proses kedua adalah bagian afektif yang menunjukkan sikap dan reaksi terhadap pesan promosi yang telah dihasilkan pada langkah tersebut. Proses terakhir adalah bagian perilaku yang merupakan pembelian aktual untuk merek yang dipromosikan . Menurut tiga proses utama ini, banyak model yang berbeda telah dibuat dan AIDA adalah salah satu model dan sering disebut.

Berdasarkan latarbelakang tersebut penelitian ini bertujuan menemukan model manajemen bisnis dan komunikasi poemasaran stasiun radio di era disgitgalisasi revolusi 4.0.

\section{Metode Penellitian}

Penelitian ini menggunakan pendekatan kualitatif yang dijelaskan secara deskriptif Pendekatan ini dipilih agar dapat mengungkapkan secara mendalam tentang strategi manajemen bisnis penyiaran radio dalam menghadapi persaingan informasi digital (Kaelan: 2012). Objek penelitian ini yaitu manajemen bisnis dan komunikasi pemasaran. Lokasi peneltian dilakukan di I-Radio Jogja. Analisis dan pengujian validitas data dilakukan dengan teknik triangulasi, yaitu pengujian dengan jalan meminta sumber lain sebagai pembanding hasil penelitian dan untuk lebih meyakinkan pernyataan yang ada. Pada penelitian ini triangulasi yang dilakukan adalah menggunakan triangulasi sumber dan data. 


\section{Hasil Penelitian Dan Pembahasan Struktur Pasar (Market Structure) I-Radio Jogja}

Terdapat perbedaan dalam kegiatan bisnis secara umum dengan bisnis media penyiaran. Bila bisnis pada umumnya menciptakan supply barang atau jasa kemudian memasarkannya (demand creates its own supply), maka pada bisnis media penyiaran (broadcast media) justru sebaliknya yaitu "supply creates its own demands" (Edwards, 2019:172). Artinya bahwa stasiun radio sebagai produsen yang menciptakan jenis jasa penyiaran baru atau baik atau handal maka selalu mendapat permintaan terhadap jasa siaran tersebut dari audience. Hal ini dapat terjadi karena sumber daya ekonomi media radio tak terbatas (unlimited resources) sedang sumber daya ekonomi lain terbatas (limited resources). Output ekonomi media seperti berita dan lagu dapat disiarkan atau dipertunjukkan lagi pada waktu dan tempat lain. Bentuk ekonomi lain dibatasi ruang dan waktu. Oleh karena itu daur produk ekonomi media radio lebih panjang. Selain itu pada ekonomi media radio hubungan biaya produksi dan pendapatan terjadi secara tidak langsung karena pendapatan pada bisnis media radio terutama berasal dari iklan.

\section{Jumlah Penjual dan Pembeli (Numbers of Sellers or Buyers)}

I-Radio Jogja dalam rangka memperoleh rating dalam hal ini berbasis pada survey AC Nielsen melalui penggunaan metode buku harian, wawancara responden, dan portable people. Metode buku harian ini semacam quosieoner yang diisi oleh koresponden penelitian yang digunakan untuk mengetahui jumlah pendengar radio. Data dari AC Nielsen 2019 pada radio wave 2 dan wave 3 berdasarkan keseluruhan pendengar secara kumulatif, I-Radio Jogja tidak berada pada urutan teratas atau tidak mengungguli radio-radio lain dari berbagai format stasiun. Namun jika dibandingkan dengan segmen sejenis seperti Swaragama dan Geronimo posisinya lebih unggul meskipun dua stasiun tersebut adalah stasiun lokal dan sudah lama eksis di Yogyakarta. Hal ini bermakna bahwa pendengar I-Radio Jogja cenderung tidak mendengarkan I-Radio Jogja secara selintas saja melainkan dalam waktu yang lama dan berkesinambungan dibandingkan radio- radio lainnya dengan segmen sejenis. Rata - rata seorang pendengar aktifmendengarkan I-Radio Jogja mendengarkan frekuensi 88,7 fm ini selama 12 menit.

Pendengar I-Radio Jogja berdasarkan jenis pendidikannya berdasarkan wave 3 tahun 2019 AC Nielsesn adalah sebanyak $43 \%$ telah menyelesaikan pendidikan SMA (Sekolah Menengah Umum) atau berstatus sebagai mahasiswa. Peringkat kedua terbanyak adalah sebanyak $31 \%$ yang memiliki tingkat pendidikan dasar (Elementary Finished) atau Sekolah Menengah Atas (SMA) sedangkan untuk peringkat ketiga adalah pendidikan SMP (Sekolah Menengah Pertama) sebanyak 14\%.

Pendengar I-Radio Jogja terbanyak adalah orang- orang yang berusia 20 hingga 24 tahun. Peringkat kedua adalah pendengar usia 2529 tahun sebesar 25\%, sedangkan pendengar dengan usia 30-34 tahun sebesar 24\%. Selebihnya kemudian diduduki oleh pendengar dengan usia lebih dari 35 tahun dan usia yang kurang dari 20 tahun. pendengar terbanyak I-Radio Jogja berasal dari golongan $\mathrm{C}$ dan golongan status B. Kondisi ini dapat dipahami karena usia 20 tahun sampai dengan 29 tahun adalah kondisi pendengar dengan status belum pekerja atau mahasiswa ataupun berstatus pegawai atau pekerja awal sehingga kondisi ekonomi yang belum mapan atau mandiri.

\section{Product Differentiation}

Melalui spesialisasi dalam pemutaran khusus musik Indonesia inilah maka I-Radio Jogja menawarkan hal yang berbeda dengan stasiun radio lainnya. Jargon 100\% musik Indonesia yang terimplementasi dengan komposisi $100 \%$ memutar musik Indonesia maka menjadikan 
strategi format staisun yang dilakukan sekaligus merupakan strategi positioning yang menunjukkan diferensiasi dengan stasiun radio lain. Indikasi atas keberhasilan format stasiun I-Radio Jogja sebagai strategi differensiasi dapat dilihat dari alasan survey AC Nielsen wave 3 Tahun 2019 bahwa umumnya pendengar atau para i-listener dalam mendengarkan dan menyimak I-Radio Jogja dikarenakan ingin mendengarkan New Release Songs atau mendengarkan lagu Indonesia rilis terbaru mengalami kenaikan tertinggi. Selain alasan tersebut juga disebabkan karena pendengar I-Radio Jogja bersifat overcome boredom yaitu mengatasi kebosanan adalah merupakan alasan mendengarkan I-Radio tertinggi.

\section{Barries to Entry}

Tantangan dan hambatan serta ancaman dalam industri media radio saat ini di Yogyakarta adalah rapatnya atau banyak jumlah stasiun radio atau lembaga siaran radio swasta. Kanal yang disediakan untuk gelombang Frequency Modulation (FM) sudah penuh pada setia kanalnya. Bila kemudian di analisis lebih detail dari 32 stasiun radio swasta di Yogyakarta beberapa diantaranya memiliki format dan positioning yang sama sehingga menambah alur kompetisi untuk bertahan hidup dan dalam mempertahankan rating.

Pada sudut pandang regulasi, pemerintah melalui keputusan KPI (Komisi Penyiaran Indonesia) Nomor 009/SK/KPI/8/2004 tentang Pedoman Perilaku Penyiaran Dan Standart Program Penyiaran telah memberikan batasan - batasan untuk pengembangan konten program acara agar tidak bertentangan dengan surat keputusan tersebut yang tidak boleh melampaui aturan - aturan yang berlaku di dalamnya. I-Radio Jogja pernah mendapat teguran dari KPID DIY dikarenakan tidak menyiarkan program acara berkonten lokal seperti kethoprak dan sebagainya. Adanya teguran tersebut pada akhirnya diantisipasi dengan program- program Insert yang bersifat kelokalan seperti Geguritan, Gudeg Manggir dan sebagainya.

Hal lain yang dilakukan oleh I-Radio Jogja dalam meningkatkan penetrasi jumlah pendengar adalah dengan mengakomodasi kebutuhan pendengar serta pelayanan yang terbaik kepada pendengar maupun klien (Keller, 2020, 63). Strategi inilah yang kemudian dilakukan oleh I-Radio dengan tetap konsisten memutar lagu Indonesia serta memberikan ruang publik untuk pendengar dan penggemar I-Radio Jogja berupa co working space. Co working space adalah fasilitas tempat para penggemar dan pendengar I-Radio beraktifitas apapun dengan fasilitas koneksi internet yang memadai serta bertujuan untuk sebagai branding ke kolega pendengar I-Radio Jogja yang kebetulan ikut datang ke ruang co working di lokasi kantor yang terletak di Jl. Gondosuli Yogyakarta.

\section{Cost Structures}

Fixed cost yang ada di I-Radio Jogja digunakan untuk pembiayaan gaji, listrik dan kesejahteraan kru I-Radio Jogja. Sedangkan untuk variabel cost adalah biaya yang dipergunakan I-Radio Jogja untuk kegiatan di luar produksi siaran seperti promosi, administrasi dan pengeluaran tidak terduga. Cost structure yang harus ditanggung oleh I-Radio Jogja dalam membiayai pengeluaran sebagai industri media, besarannya berkisar 100 juta lebih per bulannya dengan pemasukkan dari iklan keseluruhannya. Selama ini kegiatan cost structure selalu dapat melaksanakan pembiayaan cost structure tersebut dengan penjualan iklan selama 16 jam lokal dan support dari pembiayaan iklan national times yang berasal dari pusat.

\section{Vertical Integration}

I-Radio Jogja sebagai radio jaringan dalam pelaksanaan vertical integration memiliki dua keuntungan yaitu menciptakan sinergi dengan stakeholder lokal, stakeholder nasional berasal dari kantor pusat serta stakeholder dari radio 
jaringan di daerah lain. Salah satu keuntungan dari kegiatan sebagai radio jaringan adalah dengan pelaksanaan cross promotion untuk menghemat pengeluaran produksi melalui promosi produk atau jasa ke jaringan stasiun radio lain yang masih dalam satu grup jaringan. Contohnya adalah iklan yang ditayangkan di I-Radio Jogja dari klien lokal maupun nasional dapat disiarkan pula melalui jaringan radio Hard-Rock FM, I-Radio Makasar, Bandung dan sebagainya.

Pelaksanaan vertical integration yang dilakukan oleh I-Radio Jogja adalah bekerjasama dengan berbagai lembaga pendidikan tinggi dan menegah, biro iklan, produsen produk dan jasa, serta lembaga pemerintahan maupun non-pemerintahan. Bentuk combination, transactions costs, dan coordinating yang dilakukan dalam rangka vertical integration yang dilakukan I-Radio Jogja adalah dengan bekerjasama dengan biro iklan dan event organizer untuk mendukung kegiatan produksi yang sifatnya off air. Kerjasama yang dilakukan tersebut berprinsip dengan menguntungkan kedua belah pihak agar masing masing dapat menjalankan fungsi dan tujuan bisnis yang ideal.

\section{Market Conduct}

Perspektif bisnis media radio dipandang sebagai industri yang berorientasi pada pendengar (listener) yang terbatas pada wilayah tertentu karena keterbatasan jangkauan siarannya. Oleh karena itu maka prespektif bisnis industri radio juga bersifat skala lokal. Ciri lain dapat dilihat dari hampir semua stasiun radio memiliki format station yang hampir sama tetapi stasiun radio yang satu dengan yang lain tidak dapat saling menggantikan dengan sempurna (subtitute). Selain itu bentuk siaran yang dilakukan memiliki kecenderungan homogen meskipun terdapat differensited. Masing-masing stasiun radio berusaha menunjukkan format station khusus mereka agar dapat dibedakan dengan stasiun radio lainnya dengan berbagai strategi yaitu gaya siaran, jenis lagu serta karateristik berbagai produk siaran lainnya yang berbeda.
I-Radio Jogja mulai mengudara pada 1 Oktober 2005, namun dalam jangka waktu 5 bulan siaran pertamanya berhasil menduduki peringkat ke 2. Berdasarkan survey AC Nielsen Wave 4 tahun 2005 (release Februari 2006), untuk Segmen usia 20-34 Tahun dan Kelas Ekonomi S.E.S: AB (menengah keatas). Identitas I-Radio Jogja beranjak naik sejak tahun 2007 dengan pengukuhan sebagai barometer musik Indonesia dan semakin meninggalkan ciri khas sebelumnya yaitu MTV on Sky yang memutar juga lagu-lagu barat.

I-Radio Jogja mampu menunjukan identitas merekasebagairadiojaringanyangbisamenyaingi dan mengalahkan kompetitornya radio lokal yang telah lebih dahulu eksis. Kenerhasilan dalam meraih pendengar dikarenakan I-Radio Jogja melakukan strategi format station yang bersifat nasional namun tidak melupakan suasana lokal serta mengedepankan selera masyarakat lokal.

Visi misi untuk tampil terdepan dalam mengusung musik Indonesia secara utuh juga sebagai bagian dari keunggulan yang dimiliki oleh I-Radio Jogja dibandingkan kompetitornya yang mengusung lagu campuran barat dan Indonesia. Specialized yang dilakukan oleh I-Radio Jogja inilah yang menjadikan I-Radio memiliki ciri khas sendiri melalui musik-musik pilihan yang enak didengar dengan profile gaya penyiar yang menyenangkan dengan gaya yang sesuai dengan selera masyarakat Yogyakarta. Pada sisi yang lain keberhasilan ini juga didukung oleh penyediaan informasi dalam satu paket selain suguhan musik dan wacana dari penyiar I-Radio Jogja.

\section{Pricing Behavior}

Strategi pricing I-Radio Jogja dalam menghadapi struktur pasar siaran radio dan persaingan merebut pendengar dan iklan adalah melalui keputusan dari Kantor Pusat MRA group. Strategi yang dlakukan adalah dengan tidak membedakan harga jual dengan harga jual kompetitor. Artinya pricing disini dengan melihat rate dari price yang berlaku di daerah 
masing-masing lokasi radio berjaringan. Untuk lebih menarik klien maka diberlakukan diskon dan sistem paket dalam penjulan kontennya, misalnya bahwa durasi waktu beriklan menentukan besarnya diskon yang diberikan semakin lama durasi kontrak iklannya maka akan semkin besar harga diskon iklan tersebut.

Melalui strategi pricing tersebut serta program konten yang menyatu dengan selera lokal maka I-Radio Jogja mampu menjangkau target listeners SES BC. Selain itu dengan strategi yang dilakukan I-Radio Jogja menjadi salah satu pilihan klien lokal dan agensi dalam beriklan. Hal ini disupport juga dengan keunikan program konten acaranya seperti I-Radio Ngantor dan I-Radio Masuk Sekolah serta peringkat di Neilsen yang naik (diatas Swaragama FM dan Geronimo) pada tahun 2018 dan 2019 sehingga menjadi senjata merebut pasar dari klien kompetitor sebelumnya karena diminati oleh klien.

\section{Product Strategy or Advertising}

Pada konteks ini strategi yang dilakukan oleh I-Radio Jogja adalah dengan melakukan tahapan sebagai berikut: a). Tujuan radio (station objectives): I-Radio Jogja konsisten dalam mengembangkan dan menyuarakan musik Indonesia menjadi tuan rumah di negeri sendiri. b). Target pendengar (target audience): khalayak potensial I-Radio Jogja adalah masyarakat dalam kategori SES BC yang disesuaikan dengan karakter masyarakat Yogyakarta serta karakteristik terhadap pandangan musik Indonesia dari usia 17 - 35 tahun. Target yang lebih spesifik adalah Pendengar yang berjiwa muda, aktif, energik, mengikuti perkembangan terkini dan yang pasti adalah cinta dan bangga terhadap musik Indonesia. c). Positioning : meskipun inti dari siaran radio terletak pada music and talk namun I-Radio Jogja tidak terpaku pada dua hal pokok tersebut. I-Radio Jogja memposisikan sebagai stasiun radio yang tidak bersifat menghibur saja dengan program acara musik dan talk show, namun juga menjadikan stasiun radio yang menyediakan konten informasi yang dibutuhkan masyarakat luas berkaitan hal-hal keren atau menjadi buzzword.

Beberapa langkah strategi dari segi program yang akhirnya menjadi kekuatan I-Radio Jogja sampai saat ini adalah: a). Selalu melakukan riset seperti memberikan quisioner kepada para pendengar tentang program acara radio yang diinginkan pendengar. Dari sinilah kemudian dijadikan strategi dalam membuat program acara unggulan. b). Mengutamakan pemutaran musik dengan sedikit iklan dan sedikit bicara dari penyiar serta bernuansa fun, entertaint, dan kehangatan kepada pendengar yang tetap dipegang oleh I-Radio Jogja. c). I-Radio Jogja merupakan stasiun radio yang mengudara selama 19 jam nonstop. d). Mempunyai program unggulan seperti "Pagi-Pagi" dan "Sore-sore". Program unggulan ini memiliki kelebihan dibandingkan dengan radio kompetitor lainnya karena selain memanjakan pendengar dengan musik lagu yang sedang hits juga diberikan informasi yang bermanfaat khas pendengar. e). I-Radio Jogja, siarannya sangat lokal dibanding dengan radio lokal sendiri yang tidak menampilkan kelokalannya, misalnya penyiar I-Radio Jogja selalu menyisipkan dialog dan aksen khas Jogja atau kata-kata plesetan khas Yogyakarta. d). Nama-nama segmen program acaranya dibuat menarik dan unik kekinian namun tidak meninggalkan kearifan lokal, seperti Icipagi, Warganet (Warta \& Gagasan Netijen), Informasi Hangat (I-Ngat).

\section{Plant Investment}

Salah satau perangkat pendukung kegiatan siaran radio adalah pemancar atau transmisi serta menara antenna pemancar. Menara atau tower antena pemancar I-Radio Jogja adalah memiliki ukuran tinggi free stand 80 meter yang berada di tower kampus Sekolah Tinggi Teknik “AKPRIND” Yogyakarta. Dengan kekuatan pemancar maksimal 8000 watt dan ukuran ketinggian antena 80 meter 
maka I-Radio Jogja mampu meng-coverage area siaran hingga seluruh wilayah provinsi DIY dan dapat diterima diseputar wilayah lain di pinggiran atau berdekatan dengan wilayah DIY yaitu kota Klaten, Magelang, Boyolali dan sebagainya sebagai bagian dari provinsi Jawa Tengah. Coverage area siaran I-Radio Jogja menjangkau radius jarak sekitar $54-60 \mathrm{~km}$.

\section{Legal Tactics}

Salah satu contoh dalam kegiatan kerjasama tersebut adalah koorperasi antara I-Radio Jogja dengan perusahaan label musik. Umumnya kebutuhan kerja sama tersebut karena perusahaan label musik membutuhkan media untuk berpromosi dan pada sisi lain I-Radio Jogja membutuhkan materi musik untuk mendukung content siarannya. Kegiatan kerja sama dengan perusahaan label musik label dilaksanakan dalam program on air dan off-air. Program on air berbentuk talk show disuatu acara unggulan dan jumpa fans atau press conference dalam bentuk off air yang dilakukan di tempat - tempat publik seperti sekolah, kampus, mall, atau rumah makan tertentu.

\section{Market Performance}

Radio dapat beroperasi dan hidup apabila mampu merebut kue iklan yang besar, namun besarnya kue iklan yang diraih dipengaruhi oleh jumlah pendengar karena menentukan rating suatu acara yang tentunya menjadi pertimbangan klien untuk memasang iklannya atau tidak. Secara akumulasi dari berbagai aspek yang diuraikan sebelumnya terlihat bahwa jumlah pendengar I-Radio jogja semakin meningkat dari kondisi ini juga terlihat bahwa jumlah penjualan iklanpun semakin meningkat. Data tahun marketing 2018 dengan data marketing tahun 2019 terjadi signifikansi yang menunjukkan adanya kenaikkan angka rata-rata penjualan on air meningkat 12 prosen pada tahun 2019 dari tahun 2018.

\section{Product efficiency}

Manajemen produksi dan manajemen administrasi di I-Radio Jogja dipimpin oleh seorang operation manager. Tugas danwewenang operation manager adalah bertanggungjawab atas segala kegiatan yang terjadi pada I-Radio Jogja, salah satunya dalam melakukan product efficiency. Product efficiency adalah melakukan proses penciptaan konsep, strategi, dan eksekusi yang terpadu kepada seluruh departemen di bawahnya secara internal dan eksternal serta melakukan pengawasan, monitoring dan evaluasi terhadap seluruh sumber daya manusia yang terdapat dalam lingkup tanggungjawabnya dengan tujuan agar masing-masing individu dapat mengoptimalkan kemampuan agar menunjang tercapainya tujuan perusahaan.

\section{Allocative Efficiency}

I-Radio Jogja sebagai anak perusahaan yang tergabung dalam MRA group memiliki kebijakan yang ketat dalam efisiensi sumberdaya manusia maupun aset serta keuangan yang dimiliki. Untuk melaksanakan hal tersebut maka restrukturisasi telah dilakukan sejak tahun 2018 yaitu dengan memangkas tau menggabungkan beberapa struktur organisasi yang sebelumnya sendirisendiri untuk digabungkan termasuk di dalamnya mengaudit ulang kebutuhan pengeluaran untuk dapat dihemat. Sebagai contoh receptionist dan secretary and traffic sudah tidak ada lagi. Untuk traffic dapat dilakukan oleh office boy sedangkan receptionist dapat dilaksanakan oleh security. Kebijakan ini memengaruhi pula budget pengeluaran gaji yang semakin dihemat serta pengeluaran lainnya. Pada hal peningkatan kapasitas SDM I-Radio Jogja selalu aktif mengirimkan personilnya dalam berbagai pelatihan dan kursus singkat yang rutin dilakukan oleh pihak MRA group sebagai induk dari I-Radio Jogja. Pelatihan terpusat tersebut bersifat reguler diselenggarakan sehingga dapat memberikan peningkatan kapasitas SDM kru I-Radio Jogja. 


\section{Progress}

Progress I-Radio Jogja dalam persaingan di Industri penyiaran radio di Jogja mengalami kemajuan yang signifikan. I-Radio Jogja dalam jangka waktu 5 bulan siaran pertamanya tahun 2005 berhasil menduduki peringkat ke 2 berdasar survey AC Nielsen Wave 4 untuk Segmen Usia 20-34 Tahun dan Kelas Ekonomi S.E.S: AB (menengah ke atas). Pada wave ke 3 tahun 2019 I-Radio Jogja mampu melakukan penetrasi Pendengar I-Radio Jogja terbesar di interval umur 20-24 tahun (data AC nielsen 2019). Pada Wave 4 tahun 2018 jumlah pendengar I-Radio Jogja 58.000 peringkat ini naik menjadi 58.000 pendengar pada wave 2 tahun 2019. Jika dibandingkan dengan kompetitor yang sama dan merupakan radio yang identetik dengan kota Yogyakarta I-Radio Jogja justru mampu melampui jumlah pendengar mereka. Hal ini juga berkelanjutan pada penetrasi iklan dengan indikator jumlah klien lokal (yang baru pertama kali beriklan di I-Radio Jogja) bertambah daripada tahun-tahun sebelumnya. Jumlah pengiklan lokal per September tahun 2019 yang berbentuk spot adalah 18.035 kali, untuk iklan spot sebanyak 2.263 dan talkshow sebanyak 30 kali.

\section{Equity}

Kebijakan dalam keseimbangan antara produsen dengan konsumen yang dilakukan I-Radio Jogja dalam penawaran iklannya adalah melalui kebijakan kooperatif kru marketing dengan melakukan kebijakan keleluasan dalam komunikasi tanpa hal yang sulit atau ribet. Selain itu dengan jumlah pendegar yang makin meningkat dan rating yang makin tinggi I-Radio Jogja tidak serta merta memberikan tekanan pada harga iklan namun justru memberikan keuntungan untuk klien dilakukan dengan cara memberikan harga yang sama dengan harga iklan komptetor namun akan disiarkan pula ke banyak radio lain dalam jaringan MRA group.
Selain dengan prinsip harga sama namun tersiarkan melalui jaringan radio sesama grup, kebijakan lainnya dalam keseimbangan ekuitas juga dilakukan dengan kebijakan diskon pada klien baru maupun klien lama. Kebijakan diskon dilakukan agar ada kontrol baik internal yang kaitannya dengan kontrol penjualan marketying nya maupun external melihjat dari harga dan diskon kompetitor. Rate iklan secara kontinue dinaikkan namun kebijakan diskon biasanya tetap diangka 40-60\% (Menyesuaikan angka deal nya biasanya kalau angka dealnya diatas 100 juta diskon bisa sampai 50\% atau bahkan diatasnya).

\section{Content Strategy}

Bisnis industri siara radio mengharuskan setiap stasiun radio merumuskan strategi konten mereka melalui berbagai macam pertimbangan sesuai riset yang dilanjutkan pada format station. Sebagian besar stasiun komersial di industri radio masuk ke dalam format yang ditentukan oleh konten yang menarik bagi khalayak tertentu (Order, Simon, 2017, 251). Konten itu mungkin gaya musik, atau mungkin berita, olahraga, atau pemrograman lain. Dengan mendefinisikan format dengan jelas, stasiun radio dapat membangun merek media mereka dan menjual iklan berdasarkan demografi yang diharapkan dari para pendengar.

Pendekatan dalam menentukan konten yang berasal dari format station tersebut selain berasaskan pada unsur demografik juga melibatkan unsur psikografik. Sisi manajemen baik produksi maupun adminstratif juga turut menentukan konten yang dibuat dalam program stasiun radio. Umumnya pendekatan bisnis dan manajemen adalah menggunakan pendekatan bauran pemasaran 4P yaitu Product (Produk), Price (Harga), Place (Tempat), Promotion (Promosi) (Kotler dan Armstrong, 1997). 


\section{Product}

Produk pada industri radio adalah program radio atau acara radio adalah segmen konten ditujukan untuk disiarkan di radio. Karena merupakan sebuah siaran dalam bentuk jasa maka dapat dikatakan program acara radio adalah bersifat intangible service (Rajagopal, 2011, 49). Format I-Radio Jogja adalah $100 \%$ Musik Indonesia yang dilakukan selama 21 jam siaran (11 jam Relay Jakarta dan 10 jam Siaran Lokal Jogja ). Format I-Radio Jogja menampilkan musik-musik negeri sendiri yang berkualitas dari era 70-an, 80-an, 90an hingga era millenium. Konsep musik yang diputar adalah lagu-lagu Indonesia yang sedang, pernah dan menjadi hits dari berbagi aliran musik seperti pop, rock, jazz, hip-hop, ska, balada sampai alternatif. Selain program yang bersifat menghibur dalam bentuk musik juga disampaikan informasi seputar album, artis maupun perjalanan karier para musisi Indonesia.

Para penyiar I-Radio Jogja aksentuasi yang dibawakan adalah mempunyai sikap bersahabat, menempatkan diri sebagai sosok yang dewasa, pemilihan kata-kata yang sesuai dengan target pendengar, menyampaikan pesan kepada pendengar dengan singkat, padat dan tidak menggurui., energik, cerdas, jahil tapi memiliki wawasan nasional serta internasional dan selalu mengikuti perkembangan trend dunia.

\section{Price}

Harga merupakan salah satu hal yang sensitif dalam sebuah bisnis. Umumnya, konsumen menjadikan harga sebagai patokan untuk membandingkan dengan kompetitor. Sehingga, penting untuk menentukan harga yang baik, karena harga berpengaruh terhadap penjualan (Shumaila, 2013:4). Beberapa penelitian menunjukan bahwa faktor yang mempengaruhi harga iklan di radio adalah: positioning radio, konsep produk, format station, profil pendengar, perencanaan dan seleksi materi siaran, dan lokasi yang strategis.
Pada bisnis industri radio harga iklan tidak selalu berpatokan pada mekanisme pasar bahkan stasiun radio dapat menaikan atau menurunkan harga rate card iklan mereka sesuai kebijakan masing-masing. I-Radio Jogja yang semakin meningkat jumlah pendegarnya dan mampu melampaui kompetitornya dalam memberikan kebijakan harga iklan dengan mengedepankan pada keseimbangan keuntungan antara klien dan stasiun I-Radio Jogja.

\section{Place}

Place dalam konteks siaran radio ditujukan untuk mendistribusikan produk atau pelayanannya kepada pendengar dan klien. Place juga bermakna lokasi fisik produk dari media penyiaran radio dipasarkan dan langkahlangkah mendistribusikan produknya (Donthu. 2011, 35). Lokasi I-Radio Jogja menempati tempat yang strategis dengan unsur bangunan yang strategis pula berada di tengah Kota Yogyakarta di antara pusat perkantoran sipil dan bisnis. Kestrategisan lokasi semakin kuat karena lokasi alamat I-Radio Jogja di Jalan Gondosuli juga berdekatan dengan area kampus serta sekolah yang umumnya para mahasiswa dan pelajar menjadi sasaran pendengar I-Radio Jogja.

Place dalam pengertian penempatan produk program siaran adalah berkaitan dengan penempatan pada regular time yaitu pada jam 10.00 sampai dengan 16.00 serta pukul $20.00-00.00$ dengan konten program acara relay dari pusat. Sedangkan waktu prime time jam 06.00 - 10.00 pagi hari disi acara unggulan Pagi-pagi, dan waktu prime time pukul 16.00 - 20.00 pada sore dan malam hari adalah acara Sore-sore. Penempatan program acara tersebut juga mengikuti ritme pembagian durasi siaran lokal 8 jam perhari untuk acara di prime time dan 10 jam untuk siaran network. Membandingkan penempatan produk program acara dengan kenaikkan jumlah pendengar pada tahun 2019 adalah bukti keberhasilan dalam memaksimalkan konten siaran dan place sehingga memberikan kesan bagi pendengar dan klien. 


\section{Promotion}

I-Radio Jogja melaksanakan promosi produk siaran mereka seperti lazimnya stasiun radio lain adalah dengan melaksanakan insert promo di sela-sela program acara baik di prime time maupun di regular time (Coffey \& Cleary, 2011:169). Selain itu achievement yang turut mendongkrak aktivitas promosi adalah sales promotion yang dilakukan oleh departemen sales I-Radio Jogja. Hingga saat ini kegiatan sales promotion telah menghasilkan 92 klien baik perusahaan besar maupun perusahaan regular skala nasional dan lokal.

Untuk semakin meningkatkan kegiatan promosi tersebut maka digunakan tools promosim lainnya yaitu menempatkan konten digital dalam aplikasi di smartphone serta konten media sosial yang sedang hits dikalangan pendengar I-Radio Jogja yaitu Instagram dan Facebook. Selain dengan tools marketing promosi tersebut I_Radio jogja juga melaksanakan event-event regular seperti: a). Signatureevent yaitu Event off air musik I-Radio dengan line up beberapa musisi nasional asal Jogja. Acara ini diadakan di Mall, Café, dan venue semi-outdoor Lainnya di sekitar Yogyakarta, b). Retentionevent: Program traktiran I-Radio Jogja berupa menonton bersama atau nonton bareng film, konser, atau pertandingan olahraga di Yogyakarta. I-Listeners bisamenontonfilmatau konserartisidola atau atlet favoritnya berlaga, bersama penyiar dari I-Radio Jogja dan c). Socialevent: I-Radio Sapu Bersih adalah kegiatan menyasar ke tempat-tempat ibadah yang ada di Yogyakarta dan sekitarnya

\section{Simpulan}

I-Radio Jogja secara umum telah melakukan mekanisme strategi bisnis dengan keunggulan yang lebih dibanding dengan radio kompetitor yang sejenis serta lokal di Yogyakarta. Struktur pasar I-radio Jogja meskipun bukan terbanyak di Yogyakarta namun memiliki pendengar dan pemirsa yang paling banyak di antara radio kompetitor sejenis. Kelebihan ini juga bisa dilihat dari fakta bahwa I-Radio Jogja adalah radio berjaringan yang usianya relatif muda dibandingkan radio kompetitor sejenis yang lebih dulu ada. Vertical Integration yang dialkuakn oleh I-Radio Jogja juga telah membawa kepada pendekatan yang baik kepada stakeholder dan klien iklan. Jalinan stakeholder bukan hanya pada tataran lokal saja namun juga tataran nasional yang disupport oleh kantor pusat dan radio sesama jaringan satu grup lainnya. Pricing yang dilakukan I-Radio Jogja menerapkan kesesuaian daya beli dan kesesuaian rating acara yang berlaku di Yogyakarta. Strategi pricing yang dilakukan adalah dengan pemberian diskon dan sistem pembelian paket siaran. Yang menarik disini semakin besar durasi waktu yang dibeli oleh klien maka semakin besar diskon yang diberikan, termasuk di dalamnya diskon dalam pembelian paket siaran. Melalui struktur organisasi yang flat dan sederhana manajemen bisnis siaran I-Radio Jogja dapat dilakukan secara efisien dan efektif. Alokasi anggaran sehingga lebih mudah disalurkan dalam operasional siaran dan produki sehingga mendukung progress dari keuntungan yang diperoleh dalam penjulan konten siaran.

Adapun saran yang dalam penelitian ini bahwa manajemen I-Radio Jogja dan MRA grup sebagai induk dari radio berjaringan masih lemah dalam manajemen sumber daya manusia. Pemberian training dan pengikutan kegiatan pelatihan baik secara teknis dan manajerial penting dilakukan oleh pihak manajemen I-Radio Jogja secara mandiri atau in house training yang rutin dilaksanakan oleh pihak MRA Group selaku induk stasiun I-Radio Jogja. Saran metodologis disarankan agar penelitian selanjutnya dapat melihat bagaimana struktur dan wacana para pendengar stasiun radio yang disebut kaum milenial atau para digital native's terkait konten program acara yang diinginkan. 


\section{Daftar Pustaka}

Anindhita, W. (2013). Efektivitas Program Siaran Konseling Di Radio Trijaya Bagi Masyarakat Kota Yogyakarta. Jurnal Komunikasi dan Bisnis, 1(2), 27 - 51.

Coffey, A.J. \& Cleary, J. (2011). Promotional Practices Of Cable News Networks: A Comparative Analysis Of New And Traditional Spaces. International Journal on Media Management, 13(3), 161-176.

Donthu, N. (2011). Positioning A Radio Station. Journal of Applied Business Research, 10(3), 21-27.

Edwards, E. (2019). Radio and audio in 2019. Journal of Radio \& Audio Media, 27(1), 170-180.

Ivanova, I., \& Deniss S. (2018). Identifying Elements of the Digital Economy Ecosystem. Journal of Business Management, 16, 5-14.

Kaelan. (2012). Metode Penelitian Kualitatif Interdisipliner. Yogyakarta: Paradigma

Kastaya, R. W. (2014). Strategi Komunikasi Pemasaran Radio Lokal Suara Surabaya, Tesis.

Keller, K. (2010). Brand Equity Management In A Multichannel, Multimedia Retail Environment. Journal of Interactive Marketing, 24, 58-70.

Kotler, A. (2012). Prinsip-Prinsip Pemasaran, Edisi ke duabelas, Jakarta: Erlangga. Kotler P., \& Keller, K. (2012). Marketing Management 14th edition, Jakarta: PT. Indeks Kelompok Gramedia.

Küng, L. (2008). Strategic management in the media: Theory to practice, Sage London.

Lestari, A. P., \& Sunarto. (2018). Eksistensi dan Gaya Kepemimpinan Radio Lokal. Jurnal Ilmu Komunikasi, 16(2), 105-114.
Maulana, N. M. (2019). Menggali Kebijakan Penyiaran Digital di Indonesia. Jurnal Ilmu Komunikasi, 17(1), 60-72. Meenaghan, T. (1991). The Role of Sponsorship in the Marketing Communication $\mathrm{Mix}$. Journal of Advertising, 110 .

Mogel, L. (2014). This Business of Broadcasting. New York: Billboard Books.

Order, S. (2017). All the lonely people, where do they all belong:1 Community radio and social connection. Radio Journal: International Studies in Broadcast \& Audio Media, 15(2), 258.

Pickton, D., \& Broderick, A. (2005). Integrated Marketing Commuunications, Financial Times Prentice Hall, London. Peter P., Michael F. S., William, E., \& McCavitt. (1991). Electronic Media Management (Second Edition), Focal Press, Boston-London. Rajagopal. (2011). Impact Of Radio Advertisements On Buying Behaviour Of Urban Commuters. International Journal of Retail \& Distribution Management, 17(1), 48-59.

Shumaila, A. (2013). Impact of Advertising On Consumers' Buying Behavior Through Persuasiveness, Brand Image, And Celebrity Endorsement. Global Media Journal, 6(2), 1-6. Undang-Undang Penyiaran Republik Indonesia No. 32 tahun 2002 Wahyudi, 2016, Dasar-Dasar Manajemen Penyiaran, Bandung: Gramedia Pustaka https : / r ad arcom.id/2019/02/02/ diakses tanggal 12 September 2019 http://kpiddiy.com/ diakses tanggal 12 September 2019 